\title{
Penerapan Metode Activity Based Costing (ABC) dalam Perhitungan Harga Pokok Produksi (HPP) Pada Griya Batik Podhek di Kecamatan Proppo Kabupaten Pamekasan
}

\author{
Desy Dwi Amitha \\ Program Studi Akuntansi Syariah, Fakultas Ekonomi dan Bisnis Islam, IAIN Madura, Indonesia \\ Email: amithadesydwi@gmail.com \\ Farid Firmansyah \\ Program Studi Akuntansi Syariah, Fakultas Ekonomi dan Bisnis Islam, IAIN Madura, Indonesia \\ Email: farid.firmansyah79@gmail.com
}

\begin{abstract}
:
This study aims to analyze the implementation of Activity Based Costing (ABC) method in calculating cost of goods manufactured/ harga pokok produksi (HPP) at Griya Batik Proppo sub-district, Pamekasan regency. This study used descriptive quantitative approach. The kinds of data used were qualitative and quantitative data. The source of data used was primary and secondary data. While the data collected method was found by three method; semi-structured interview, the documentation of batik production process and observation method at Griya Batik Podhek. The results of this study showed cost of goods manufactured per-sheet of cloth batik by traditional method as much as Rp1.819.598,-. When using the method of Activity Based Costing (ABC) was obtained cost of goods manufactured Rp1.498.783,798,-. From both calculating, between traditional method and Activity Based Costing (ABC) method has difference cost of goods manufactured was Rp320.814,202,-. Basic price result was obtained by using both calculations found that the calculating cost of goods manufactured by Activity Based Costing (ABC) was cheaper than using traditional method. By knowing the difference cost of goods manufactured which resulted, so it was known the real profit obtained.
\end{abstract}

Keywords: Activity Based Costing (ABC) and Cost of goods manufactured (HPP).

\begin{abstract}
Abstrak:
Penelitian ini bertujuan untuk menganalisis penerapan metode Activity Based Costing (ABC) dalam perhitungan harga pokok produksi (HPP) di Griya Batik Podhek Kecamatan Proppo Kabupaten Pamekasan. Penelitian ini menggunakan pendekatan kuantitatif deskriptif. Jenis data yang digunakan yaitu data kualitatif dan kuantitatif. Untuk sumber data yang digunakan yaitu data primer dan data sekunder. Sedangkan metode pengumpulan data diperoleh dengan tiga metode yaitu metode wawancara semi struktur, metode dokumentasi dari proses produksi batik dan menggunakan metode observasi di griya batik podhek. Hasil penelitian menunjukkan bahwa harga pokok produksi per lembar kain batik dengan metode tradisional sebesar Rp Rp1.819.598,- sedangkan apabila menggunakan metode Activity Based Costing (ABC) diperoleh HPP sebesar Rp Rp1.498.783,798,-. Dari kedua perhitungan tersebut, antara metode tradisional dan metode Activity Based Costing (ABC) memiliki selisih beda harga pokok produksi yang dihasilkan yaitu sebesar Rp320.814,202,-. Hasil harga pokok yang diperoleh dengan menggunakan dua perhitungan tersebut diketahui bahwa perhitungan HPP dengan metode Activity Based Costing (ABC) lebih murah dari pada menggunakan metode tradisional. Dengan diketahuinya perbedaan harga pokok produksi yang dihasilkan, maka diketahui pula laba sebenarnya yang diperoleh.
\end{abstract}

Keywords: Activity Based Costing (ABC) dan Harga Pokok Produksi (HPP). 


\section{PENDAHULUAN}

UNESCO (United Educational, Scientific, and Curtural Organization) pada tanggal 2 Oktober 2009 menetapkan batik sebagai warisan budaya dunia yang berasal dari Indonesia dengan istilah "Warisan Kemanusiaan untuk Budaya Lisan dan Nonbetawi". Batik dinilai sebagai ikon budaya yang memiliki keunikan dan filosofi yang mendalam, serta mencakup siklus kehidupan manusia. ${ }^{1}$

Batik memiliki tata warna dan corak yang khas yang dimiliki oleh sebuah daerah yang menjadi identitas bangsa Indonesia. Batik juga menjadi sebuah karya budaya yang memiliki nilai ekonomi tinggi, karena menjadi sumber kehidupan bagi pengerajinnya, membuka lapangan usaha, manambah devisa negara, dan menjadi potensi wisata. Kota Yogyakarta, Solo, Pekalongan, Cirebon, Lasem, Tasikmalaya, Kalimantan Timur, Madura, dan Bali adalah beberapa deretan kota yang menjadi pusat batik. $^{2}$

Sejalan dengan itu, batik tulis Madura mulai merebut pasar dalam negeri yang dipelopori oleh batik yang berasal dari Kecamatan Tanjung Bumi, Kabupaten Bangkalan, yang dikenal dengan nama batik Tanjung Bumi. Mengiringi kebangkitan batik Tanjung Bumi, batik di tiga kabupaten lainnya juga bangkit yakni Kabupaten Sampang, Kabupaten Pamekasan, dan Kabupaten Sumenep. ${ }^{3}$

Di Pamekasan, batik menemukan lahan yang subur dan berkembang hampir di seluruh wilayah. Batik menjadi komoditas andalan dan menjadi ikon industri kecil. ${ }^{4}$ Kabupaten Pamekasan adalah salah satu kabupaten yang dinobatkan sebagai kabupaten batik pada tahun 2009 dengan adanya pemecahan rekor muri batik terpanjang dengan panjang batik tulis sepanjang 1530 meter. Lokasi kerajinan batik di Kabupaten Pamekasan menyebar di sebelas Kecamatan, dengan jumlah terbanyak di Kecamatan Proppo. Salah satu sentra yang terletak di kecamatan Proppo yaitu di Desa Rang Perang Daya. ${ }^{5}$

Sejauh ini, batik Pamekasan tidak hanya digemari oleh masyarakat lokal saja, namun banyak masyarakat luar daerah bahkan luar negeri yang menggemari batik Pamekasan. Wisatawan yang datang ke Pamekasan sering kali menjadikan batik sebagai oleh-oleh atau cinderamata. Batik Podhek adalah salah satu batik yang sangat digemari keberadaannya. Batik ini memiliki ciri khas tersendiri yaitu tingkat ketelitian motif yang sangat tinggi, detail dan juga motifnya yang terkenal halus. Ciri khas inilah yang menjadikan Batik Podhek di Kecamatan Proppo banyak digemari oleh wisatawan hingga ke manca negara seperti Malaysia, Belanda, Venezuela, dan Jepang. Untuk itu, diperlukan perhatian untuk kelangsungan produksi kain batik Pamekasan dengan upaya peningkatan hasil produksi dengan tetap mempertimbangkan mutu dan efisiensi produksi. Saat ini, jumlah pengerajin batik di daerah Pamekasan semakin meningkat, hal ini berarti semakin tinggi pula tingkat persaingan produk sejenis.

Activity Based Costing (ABC) adalah sebuah sistem yang berfokus pada aktivitas sebagai objek biayanya dan menggunakan akivitas biaya tersebut sebagai cost driver bagi objek biaya selain aktivitas. Activity Based Costing bersifat generik yakni dapat menjadi bagian dari sistem

\footnotetext{
${ }^{1}$ Kadarisman Sastrodiwirjo, The Heritage of Indonesia Pamekasan Membatik, (Pamekasan: Bagian Humas dan Protokol Setda Kabupaten Pamekasan, 2017), hlm. 10.

${ }^{2}$ Encus Dyah AyoeMoerniwati, "Studi Batik Tulis (Kasus di Perusahaan Batik Ismoyo Dukh Butuh Desa Gendongan Kecamatan Plupuh Kabupaten Sagen)”, Jurnal Program Studi Pendidikan Seni Rupa, Universitas Sebelas Maret, Vol. 1 No. 1 (2013), hlm. 1-2.
}

${ }^{3}$ Kadarisman Sastrodiwirjo, The Heritage of Indonesia Pamekasan Membatik, hlm. 24.

${ }^{4}$ Ibid. 25.

${ }^{5}$ Ibid. 83.

150

Shafin: Sharia Finance and Accounting Journal

Vol.1 No.2 September 2021 
penetapan harga pokok produk baik bersifat job order atau sistem pokok proses. ${ }^{6}$ Aktivitas harus dilakukan secara efektif dan efesien agar biaya juga efesien. Efektif artinya sasaran kerja cepat dicapai, dan efesien artinya pengorbanan input harus serendah mungkin atau sekompetitif mungkin. ${ }^{7}$

Biaya overhead pabrik harus ditelusuri berdasar aktivitas produk yang mengkonsmsinya. Kalkulasi dari biaya berdasarkan aktivitas adalah perhitungan biaya produk didasarkan aktivitas nyata pengorbanan input untuk memperoleh output. Setiap produkharus ditelusuri biayanya berdasarkan aktivitas untuk menciptakan produk tersebut, dimulai dari riset pasar sampai dengan pelayanan purna jual. Tujuan perhitungan model ini adalah untuk menentukan objek biaya secara akurat.

Keakuratan biaya produk menentukan keakuratan kebijakan harga. Biaya produk yang akurat, kebijakan harga lebih mudah ditentukan. Selain itu, perhitungan laba atau rugi usaha mencerminkan kondisi bisnis yang sesungguhnya. Laba adalah tujuan akhir kegiatan bisnis. Laba harus dihitung secara cermat berdasarkan kondisi pasar dan kondisi biaya keseluruhan kehidupan produk. Dengan keakuratan biaya ini dapat memenuhi keperluan intern perusahaan untuk pengambilan keputusan seperti menetapkan harga penawaran yang nantinya harus dibebankan kepada produk yang bersangkutan, kemudian dihitung biaya per unitnya. ${ }^{8}$

Di era global seperti saat ini perusahaan diharuskan untuk meningkatkan efisiensi serta efektivitas proses produksinya agar dapat meningkatkan daya saing. Persaingan saat ini tidak hanya menuntut perusahaan untuk memproduksi barang sebanyak-banyaknya namun bagaimana produsen barang tersebut tepat dalam metode perhitungan harga produksinya. Apabila perhitungan harga pokok produksi kurang tepat dalam perhitungannya, maka yang akan terjadi adalah harga barang produksi terlalu mahal sehingga produk tidak diminati konsumen, sebaliknya apabila harga terlalu rendah memang akan menarik minat konsumen untuk membeli produk hasil produksi perusahaan namun hal ini menyebabkan hasil penjualan tidak dapat menutup biaya produksi apabila keadaan ini terus berlanjut maka dapat menyebabkan kebangkrutan perusahaan. ${ }^{9}$

Penentuan harga pokok produksi dapat dilakukan dengan menggunakan metode full costing, variabel costing atau dengan sistem activity based costing. Namun untuk metode full costing atau konvensional tidak terdapat pemisahan biaya-biaya ke dalam biaya tetap dan biaya variabel sehingga terjadi banyak sekali distorsi dalam penentuan harganya karena sistem pembebanan biaya tidak diperhitungkan secara detail.

Berdasarkan hasil wawancara dengan Bapak Hadi selaku pengrajin dan pemilik Griya Batik Podhek diketahui bahwa dalam memproduksi batik terdapat dua jenis kualitas yaitu jenis premium dan nonpremium. Hasil kerajian batik memiliki harga yang berbeda-beda tergantung dari kualitas batik dan tingkat kehalusan hasil batik yang diproduksi. Dalam penentuan harga pokok produksi pada Griya Batik Podhek Kecamatan Proppo Kabupaten Pamekasan ini masih menggunakan metode tradisional. Metode tradisisional yang dimaksud ini yaitu dengan menjumlahkan biaya produksi yang dibagi dengan unit yang dihasilkan. Metode ini tidak menghitung secara rinci biaya-biaya yang dikeluarkan dalam proses produksi,

\footnotetext{
${ }^{6}$ Samryn, Akuntansi Manajemen (Jakarta: Kencana,2012), hlm. 143.

${ }^{7}$ Darsono Prawironegoro, dkk., Akuntansi Manajemen Edisi 3 (Jakarta: Mitra Wacana Media, 2009), hlm. 34.

${ }^{8}$ Ari Purwanti, dkk., Akuntansi Manajemen (Jakarta: Mitra Wacana Media, 2013), hlm.43.

${ }^{9}$ Dyah Ayu Setyaningrum, Analisis Penentuan Harga Pokok Produksi Batik Mustika Blora Berdasarkan Sistem Activity Based Costing (Studi Kasus pada Usaha Batik Mustika Blora) (Skripsi: Universitas Negeri Semarang, 2013), hlm. 1.
} 
serta menetapkan harga jual berdasarkan harga pokok produksi tadi ditambah dengan persentase laba yang diinginkan. Sehingga, harga pokok produk yang belum jelas akan mengakibatkan keuntungan bersih dari hasil produksi tidak dapat diketahui secara pasti. ${ }^{10}$

Berdasarkan hasil penelitian terdahulu dengan judul "Penentuan Harga Pokok Produksi Batik pada Griya Batik Gress dengan Metode Activity Based Costing (ABC) (Studi Kasus di Griya Batik Gress Tenan Laweyan)".Dari hasil penelitian yang dilakukan oleh Tri Mardian Shaleh menyimpulkan bahwa "dengan menggunakan metode ABC tersebut diperoleh harga pokok produksi yang lebih murah dan dapat memperoleh laba lebih banyak dibandingkan dengan menggunakan metode tradisional". ${ }^{11}$

Untuk itu, penetapan harga pokok produksi dengan menggunakan metode Activity Based Costing (ABC) yang menguraikan pembiayaan produksi batik melalui aktivitas-aktivitas produksi yang dilakukan secara rinci dan detail dapat

dipergunakan oleh pengrajin batik di Griya Batik Podhek Kecamatan Proppo Kabupaten Pamekasan agar penentuan harga pokok produksi dapat dihitung secara akurat dan tepat hingga nantinya dapat diketahui secara pasti laba yang sebenarnya dan tercapainya tingkat efektifitas dan efesiensi dari produksi Batik. Berdasarkan permasalahan tersebut, penulis tertarik untuk meneliti permasalahan tersebut.

\section{METODOLOGI PENELITIAN}

Rancangan penelitian atau desain penelitian bermakna untuk mengatur latar (setting) penelitian agar peneitian dapat memperoleh data yang valid sesuai dengan karakterstik variabel dan tujuan penelitian. Rancangan penelitian menjelaskan tentang jenis penelitian ditinjau dari tujuan dan sifatnya.

Penelitian ini termasuk penelitian kuantitatif yaitu "suatu proses menemukan pengetahuan yang menggunakan data berupa angka sebagai alat menemukan keterangan mengenai apa yang ingin diketahui". ${ }^{12}$ Jenis penelitian dalam penelitian ini adalah jenis penelitian deskriptif, yaitu "penelitian yang dilakukan untuk memberikan gambaran yang lebih detail mengenai suatu gejala atau fenomena".13

Penelitian deskriptif kuantitatif adalah "salah satu jenis penelitian yang bertujuan untuk mendeskripsikan secara sistematis, faktual, dan akurat mengenai fakta dan sifat populasi tertentu, atau mencoba menggambarkan fenomena secara detail dan memberikan jawaban terhadap suatu masalah untuk mendapatkan informasi yang lebih luas dan mendalam dari fenomena dengan pendekatan kuantitatif". ${ }^{14}$

Tidak semua penelitian kuantitatif memerlukan hipotesis penelitian. Penelitian kuantitatif yang bersifat deskriptif tidak membutuhkan hipotesis, karena jenis penelitian

\footnotetext{
${ }^{10}$ Hadi, Pemilik Griya Batik Podhek, Wawancara Tidak Langsung, (29 Agustus 2019).

${ }^{11}$ Tri Mardian Saleh, Penentuan Harga Pokok Produksi Batik pada Griya Batik Gress Tenan dengan Metode Activity Based Costing (ABC) Studi Kasus di Griya Batik Gres Tenan (Skripsi: Universitas Muhammadiyah Surakarta, 2014), $\quad$ hlm. $\quad 8-9, \quad$ diakses pada https://www.google.com/url?sa=t\&source=web\&rct=j\&url=http://eprints.ums.ac.id/32376/14/NASKAH\%25 20PUBLIKASI.pdf\&ved=2ahUKEwiNy_6ppuvIAhXMfH0KHUhOCvoQFjABegQIBRAI\&usg=AOvVaw2t t2LzfNosW_Kt7p-8Zutr

${ }^{12}$ DeniDarmawan, Metode Penelitian Kuantitatif (Bandung: PT. Remaja Rosdakarya, 2013 ), hlm. 37.

${ }^{13}$ Bambang Prasetyo dan Lina Miftahul Jannah, Metode Penelitian Kuantitatif (Jakarta: PT. RajaGrafindo Persada, 2005), hlm. 47.

${ }^{14}$ Muri Yusuf, Metode Penelitian: Kuantitatif, Kualitatif, dan Penelitian Gabungan (Jakarta: Kencana, 2014), hlm. 62 .

152
}

Shafin: Sharia Finance and Accounting Journal

Vol.1 No.2 September 2021 
tersebut tidak bertujuan menguji hipotesis melainkan bertujuan untuk membuat diskripsi mengenai hal-hal yang diteliti terhadap suatu perusahaan. ${ }^{15}$

Objek yang dipilih dalam penelitian ini adalah Griya Batik Podhek yang terletak di Dusun Podhek Desa Rang Perang Daya Kecamatan Proppo Kabupaten Pamekasan. Griya Batik Podhek ini adalah usaha yang bergerak pada bidang industri batik. Batik merupakan kain kerajinan tangan (hand made) yang prosesnya melalui perintangan warna memakai malan (sejenis lilin) dan dilakukan pewarnaan sehingga menghasilkan motif gambar sesuai sketsa yang dibuat oleh pembatik itu sendiri.

Jenis data yaitu "kelompok data menurut sifatnya". Pengelompokan data menurut sifatnya dibagi menjadi dua kelompok data, yaitu:

a. Data kualitatif, adalah "data yang berupa pendapat (pernyataan) atau judgement sehingga tidak berupa angka akan tetapi berupa kata-kata atau kalimat". ${ }^{16}$ Data kualitatif dalam penelitian ini terdiri dari:

1) Gambaran umum perusahaan meliputi lokasi dan struktur perusahaan.

2) Sejarah mengenai awal pendirian usaha, kelembagaan, dan inovasi.

3) Jenis dan bahan yang digunakan dalam produksi

4) Proses produksi

5) Ketentuan penetapan harga

b. Data kuantitatif, adalah "data yang berupa angka". Dalam penelitian ini terdiri atas:

1) Data biaya produksi

2) Penetapan harga jual

3) Sumber daya yang dimiliki, material, dan tenaga kerja dalam proses produksi

Sumber data adalah "kelompok data menurut cara memperolehnya". Terdapat dua jenis data dalam kelompok ini, yaitu: Data primer. Data sekunder.

Pengumpulan data adalah "suatu proses pengumpulan data primer dan sekunder". Data yang digunakan dalam penelitian ini diperoleh peneliti dengan menggunakan tiga metode, yaitu:

1. Metode wawancara

2. Metode observasi. ${ }^{17}$

3. Metode Dokumentasi.

Analisis data yang digunakan dalam penelitian ini menggunakan metode analisis deskriptif yaitu "sebuah analisis data yang digunakan untuk menyajikan informasi yang memaparkan hasil penelitian yang dilakukan oleh peneliti dan menggambarkan mengenai kondisiyang diteliti". ${ }^{18}$ Dalam hal ini mengenai proses produksi pada griya batik Podhek sehingga menghasilkan data-data yang dibutuhkan dalam rangka penerapan metode Activity Based Costing (ABC) dalam menentukan (HPP) harga pokok produksi pada Griya Batik Podhek di Kecamatan Proppo Kabupaten Pamekasan.

Langkah pertama yang dilakukan dari data penelitian yaitu melakukan analisis perhitungan harga pokok produksi dengan menggunakan metode tradisional dengan cara (1)

\footnotetext{
${ }^{15}$ Tim Penyusun, Pedoman PenulisanKarya Ilmiah Edisi Revisi 2015, hlm. 11.

${ }^{16}$ Syofian Siregar, Metode Penelitian Kuantitatif (Jakarta: Kencana Prenadamedia Grup, 2013), hlm. 16-17.

${ }^{17}$ Ibid. 19.

${ }^{18}$ Made Wirartha, Pedoman Penulisan Usulan Penelitian, Skripsi, dan Tesis (Yogyakarta: Cv. Andi Offset, 2006), hlm. 111.
} 
identifikasi unsur-unsur harga pokok produksi, (2) perhitungan biaya per variabel, (3) perhitungan harga pokok produksi per unit.

Selanjutnya, melakukan analisis data penelitian dengan sistem Activity Based Costing ini. Langkah pertama untuk menentukan harga pokok produksi dengan metode ABC yaitu dengan mengalokasikan biaya overhead dari data yang diperoleh yang terdiri dari dua tahap yaitu: ${ }^{19}$

1. Prosedur Tahap Pertama

a. Mengidentifikasi aktivitas

b. Menentukan biaya yang terkait dengan masing-masing aktivitas

c. Mengelompokkan aktivitas yang seragam menjadi satu

d. Menggabungkan biaya aktivitas yang dikelompokkan

e. Menghitung tarif per kelompok aktivitas

2. Prosedur Tahap Kedua

a. Membebankan biaya aktivitas kepada produk

Setelah penelusuran dan pembebanan biaya aktivitas selesai dilakukan, langkah berikutnya adalah membebankan biaya aktivitas tersebut ke masingmasing produk yang menggunakan cost driver. Setelah tarif per kelompok aktivitas diketahui, maka dapat dilakukan perhitungan biaya overhead yang dibebankan pada produk sebagai berikut:20

Setelah didapat jumlah overhead yang dibebankan, maka dapat dihitung HPP (Harga pokok Produksi) dari produksi batik adalah sebagai berikut:

\section{Overhead Yang Dibebankan = Tarif Kelompok xJumlah Konsumsi Tiap Hari}

$$
\begin{aligned}
\text { Harga Pokok Produksi Per Unit }= & \text { Biaya Bahan Baku+Biaya } \\
& \text { Tenaga Kerja Langsung+Biaya }
\end{aligned}
$$

\section{HASIL PENELITIAN}

Griya Batik Podhek adalah salah satu rumah produksi batik milik Bapak Hadi yang berlokasi di Dusun Podhek Desa Rang Perang Daya, Kecamatan Proppo Kabupaten Pamekasan. Griya Batik Podhek telah terdaftar menjadi IKM (Industri Kecil Menengah) sejak tahun 2011 dengan nomer izin 69/IND/VII/2011.21 Visi dan Misi dari usaha griya batik podhek yaitu melestarikan budaya yang berdampak pada kesejahteraan masyarakat.

Berdasarkan pemaparan langsung dari Bapak Hadi bahwa Griya Batik Podhek ini berdiri sejak tahun 2012. Pada awal pendiriannya keberadaan batik mulai langka bahkan hampir punah. Hal ini disebabkan karena masyarakat dusun podhek lebih berfokus kepada

\footnotetext{
${ }^{19}$ Kamaruddin Ahmad, Akuntansi Manajemen, hlm. 17.

${ }^{20}$ Rudianto, Akuntansi Manajemen, hlm. 166.

${ }^{21}$ https://disperindag.pamekasankab.go.id/ikm-binaan/ diakses pada Minggu, 22 Desember 2019 pukul 10.08 WIB. 
mata pencarian sebagai seorang petani. Oleh sebab itu, Bapak Hadi mencoba untuk berinovasi agar batik kembali diperhatikan oleh masyarakat setempat dengan memberikan inovasi baru.

Pada tahun 2013, berawal saat kompetisi batik se-Jawa Timur, anak didikan Bapak Hadi diikut sertakan dalam kompetisi tersebut dan mendapat banyak juara. Tahun 2013 menjadi tahun prestasi pertama yang didapat oleh Bapak Hadi dan anak didiknya dan terus mengalami perkembangan sampai saat ini.

Motif yang di desain pada awal pendirian masih tergantung pada pangsa pasar. Pada saat itu, harga batik yang ditawarkan masih sekitar Rp60.000 saja. Untuk itu, Bapak Hadi berkeinginan untuk meningkatkan harga jual di pasaran dengan memberikan inovasi jenis batik baru yaitu jenis premium. Pada dasarnya, Bapak Hadi adalah seseorang yang memiliki kemampuan pada bidang kaligrafi saja.

Inovasi adalah ide atau gagasan yang diciptakan dengan tujuan untuk meningkatkan ketertarikan konsumen terhadap batik podhek. Bapak Hadi menjelaskan mengenai inovasi yang dilakukan yaitu:22

"Inovasi yang saya lakukan yaitu dengan meningkatkan jenis kualitas batik yang pada awalnya hanya berjenis non premium (kualitas biasa) menjadi jenis premium. Hal ini diwujudkan dengan perubahan bahan baku yang digunakan, yang pada awalnya masih menggunakan kain jenis primisima cap-sen, kini dikembangkan ke kain jenis tariuko sampai jenis kereta kencana. Dan untuk malan, yang pada awalnya menggunakan jenis malan biasa dengan harga Rp14.000-Rp20.000, kini sudah menggunakan malan dengan harga Rp35.000-Rp70.000 dengan kualitas terbaik. Dan juga untuk pewarna yang digunakan pada awalnya hanya warna Napthol dan Rapidol, kini menggunakan indegosol dan remasol. Dan untuk jenis premium menggunakan pewarna jenis Napthol dan Indigosol. Yang menjadi pembeda yaitu penggunaan canting pada jenis premium. Pada jenis premium ini menggunakan ukuran canting nomer 1 yang berarti memiliki ukuran diameter lubang yang sangat kecil hingga mampu menciptakan goresan malan pada motif yang semakin halus atau kecil. Sistem produksi yang paling membedakan antara produksi batik jenis premium dan non premium adalah jika non premium tidak semuanya dikerjakan di Griya Podhek saja. Akan tetapi batik mentah atau batik putihan dibeli ke daerah lain yang sudah di gambar dan di malan dan sudah ada reng-rengan. Jadi, memang batik putihan dibeli dari pasar yang disediakan dari daerah toke dan candi burung, dan untuk proses pewarnaan sampai finishing dilakukan di Griya Podhek untuk yang jenis non premium. Untuk yang reguler (termasuk dalam jenis non premium) yang harganya diatas Rp150.000-Rp750.000 biasa dikerjakan di Podhek. Kalau jenis premium, dari awal proses pengkattelan sampai finishing semuanya dikerjakan di Griya Batik Podhek. Untuk yang reguler ini dikerjakan oleh anak didik yang masih pemula. Jadi sebelum beranjak ke batik jenis premium, sebelumnya dilatih di jenis non premium. Jadi pada intinya batik premium dikerjakan dari mentah, sedangkan untuk batik jenis non premium mentah dari luar dan finishing dari sini untuk harga jual kisaran Rp75.000-Rp150.000".

Awalnya dirasa sangat sulit untuk bisa meyakinkan masyarakat, namun setelah sedikit demi sedikit dijalankan mulai bisa dirasakan keuntungan yang didapat dari pada keuntungan yang didapat sebelumnya. Hal ini menambah semangat dan keyakinannya dalam membuat masyarakat semakin tertarik.

\footnotetext{
${ }^{22}$ Hadi, Pemilik Griya Batik Podhek, Wawancara Langsung, (24 Desember 2019).
} 


\section{Temuan Penelitian}

Setelah melakukan penelitian dengan menggunakan metode wawancara dan observasi, peneliti menemukan beberapa hal penting mengenai produksi batik Podhek baik dalam pembagian jenis produk, proses produksi produk, sistem produksi, dan juga penetapan harga jual per produknya.

Berdasarkan wawancara dan observasi yang dilakukan, griya batik Podhek memproduksi dua jenis batik yaitu jenis premium dan jenis non premium. Namun, untuk jenis non premium menjadi tanggung jawab saudara pemilik, tetapi tetap dalam satu manajemen. Bapak Hadi lebih berfokus kepada pengerjaan batik jenis premium saja. Untuk itu, peneliti berfokus pada jenis premium karena produksi jenis premium dilakukan secara terpisah dengan produksi jenis non premium yang berarti tidak terjadi distorsi biaya dalam setiap produksinya.

Dalam proses produksi batik jenis premium, griya batik Podhek hanya menghasilkan empat lembar kain batik saja dalam waktu pengerjaan dua bulan. Ini berarti griya batik Podhek sangat intensif terhadap proses produksinya seperti saat proses pemalaman yang membutuhkan waktu pengerjaan hingga sebanyak 49 hari untuk setiap lembarnya. Tidak seperti jenis batik biasa yang pengerjaannya relatif singkat. Hal ini dikarenakan desain motif yang di desain langsung oleh pemilik yakni batik jenis premium adalah motif yang memiliki kerapatan tinggi, hal itulah yang menyebabkan proses pemalaman membutuhkan waktu yang relatif lama dan harus dilakukan secara tekun.

Sistem produksi yang digunakan oleh griya batik podhek ini menggunakan sistem borongan. Sistem borongan yang dimaksud adalah satu pekerja bertanggung jawab untuk penyelesaian satu lembar kain batik dari proses pemalaman sampai selesai dengan perhitungan upah harian yang dihitung saat produksi selesai (dua bulan).

Harga jual yang ditetapkan oleh griya batik podhek yaitu tergantung dari biaya produksi yang dikeluarkan dan persentase laba yang diinginkan. Persentase laba yang diinginkan oleh griya batik podhek untuk jenis non premium yaitu $30 \%$ dari biaya produksi, dan untuk jenis premium yaitu 100\%-200\% dari biaya produksi yang dikeluarkan. Ini berarti semakin murah harga pokok produksi yang dihasilkan, maka semakin murah pula harga jual yang akan ditawarkan. Untuk itu peneliti menggunakan metode Activity Based Costing untuk menganalisis perhitungan harga pokok produksi dengan berfokus pada aktivitas produksi dan menganalisis cost driver atau penyebab biaya dari masing-masing aktivitas dan membandingkan dengan penggunaan perhitungan sebelumnya (metode tradisional). Perhitungan Activity Based Costing ini adalah metode yang merinci setiap aktivitas untuk dapat menghasilkan harga pokok produksi yang akurat dan mengetahui laba yang sesungguhnya.

\section{PENUTUP}

Berdasarkan hasil penelitian mengenai penerapan metode Activity Based Costing (ABC) dalam perhitungan harga pokok produksi (HPP) pada Griya Batik Podhek di Kecamatan Proppo Kabupaten Pamekasan, maka dapat disimpulkan bahwa perhitungan harga pokok produksi per lembar kain batik dengan menggunakan metode tradisional diperoleh sebesar Rp1.819.598,-- sedangkan apabila menggunakan metode Activity Based Costing (ABC) diperoleh sebesar Rp Rp1.498.783,798,-. Dari kedua perhitungan tersebut, memiliki selisih beda harga pokok produksi yang dihasilkan yaitu sebesar Rp320.814,202,-. Hasil perhitungan harga pokok produksi yang diperoleh dengan menggunakan perhitungan Activity Based Costing lebih murah dari pada menggunakan metode tradisional. Dengan diketahuinya perbedaan harga 
pokok produksi maka diketahui pula laba sebenarnya yang diperoleh. Hal ini akan berpengaruh pula terhadap harga jual yang ditawarkan.

\section{DAFTAR RUJUKAN}

Ahmad, Kamaruddin. Akuntansi Manajemen. Jakarta: PT. RajaGrafido Persada, 2014.

Bustami, Bastian dan Nurlela. Akuntansi Biaya. Jakarta: Mitra Wacana Media, 2013.

Darmawan, Deni. Metode Penelitian Kuantitatif, Bandung: PT. Remaja Rosdakarya, 2013.

Horngren, Charles T, S. M. Datar, dan G. Foster. Akuntansi Biaya Dengan Penekanan Manajerial. Jakarta: Erlangga, 2008.

Islahuzzaman. Activity Based Costing Teori dan Aplikasi. Jakarta: Alfabeta, 2011.

Jusup, Al. Haryono. Dasar-Dasar Akuntansi. Yogyakarta: Bagian Penerbitan Sekolah Tiggi Ilmu Ekonomi YKPN, 2011.

Krismiaji dan Y Anni Aryani. Akuntansi Manajemen. UPP STIM YKPN: Yogyakarta.

Moerniwati, Encus Dyah Ayoe. "Studi Batik Tulis (Kasus di Perusahaan Batik Ismoyo Dukh Butuh Desa Gendongan Kecamatan Plupuh Kabupaten Sagen)", Jurnal Program Studi Pendidikan Seni Rupa, Universitas Sebelas Maret, Vol. 1 No. 1, 2013.

Mulyadi. Akuntansi Biaya.Yogyakarta: UPP STIM YKPN, 2005.

Pirmaningsih, Lilik. Akuntansi Manajemen. Jakarta: Mitra Wacana Media, 2014.

Prasetyo, Bambang dan L. M Jannah. Metode Penelitian Kuantitatif, Jakarta: PT. RajaGrafindo Persada, 2005.

Purwanti, Ari dan D. Prawironegoro. Akuntansi Manajemen. Jakarta: Mitra Wacana Media, 2013.

Qodratillah, Meity Taqdir. Kamus Bahasa Indonesia untuk Pelajar. Jakarta: Badan Pengembangan dan Pembinaan Bahasa Kementrian Pendidikan dan Kebudayaan, 2011.

Rudianto. Akuntansi Manajemen. Jakarta: Erlangga, 2013.

Saleh, Tri Mardian. Penentuan Harga Pokok Produksi Batik pada Griya Batik Gress Tenan dengan Metode Activity Based Costing (ABC) Studi Kasus di Griya Batik Gres Tenan. Skripsi: Universitas Muhammadiyah Surakarta, 2014.

Samryn. Akuntansi Manajemen. Jakarta: Kencana, 2012.

Sarwono, Jonathan. Metode Penelitian Kuantitatif dan Kualitatif, Yogyakarta: Graha Ilmu, 2006.

Sastrodiwirjo, Kadarisman. The Heritage of Indonesia Pamekasan Membatik, Pamekasan: Bagian Humas dan Protokol Setda Kabupaten Pamekasan, 2017.

Satria, Hendy. Penerapan Metode Activity Based Costing untuk Menentukan Harga Pokok Produksi. Jurnal Benefita.

Setyaningrum, Dyah Ayu. Analisis Penentuan Harga Pokok Produksi Batik Mustika Blora Berdasarkan Sistem Activity Based Costing (Studi Kasus pada Usaha Batik Mustika Blora). Skripsi: Universitas Negeri Semarang, 2013.

Siregar, Syofian. Metode Penelitian Kuantitatif.Jakarta: Kencana Prenadamedia Grup, 2013.

Sjahrial, Dermawan, dan D. Purba. Akuntansi Manajemen. Jakarta: Mitra Wacana Media, 2012.

Sugiyono. Metode Penelitian Pendidikan Pendekatan Kuantitatif dan Kualitatif. Bandung: Alfabeta, 2008.

Sukirno, Sadono. Mikro Ekonomi Teori Pengantar. Jakarta: Rajawali Pers, 2002.

Supriyono, Akuntansi Biaya Pengumpulan Biaya \& Penentuan Harga Pokok, Yogyakarta: BPFE, 1983. 
Desy Dwi Amitha, Farid Firmansyah

Tim Penyusun. Pedoman Penulisan Karya Ilmiah Edisi Revisi 2015. Pamekasan: STAIN Pamekasan, 2015.

Wirartha, Made. Pedoman Penulisan Usulan Penelitian, Skripsi, dan Tesis, Yogyakarta: Cv. Andi Offset, 2006.

Witjaksono, Armanto. Akuntansi Biaya, Yogyakarta: Graha Ilmu, 2006.

Yusuf, Muri. Metode Penelitian: Kuantitatif, Kualitatif, dan Penelitian Gabungan, Jakarta: Kencana, 2014. 